\title{
Qualidade Microbiológica de Ricotas Comercializadas Na Cidade de Concórdia, Sc
}

Mariane Ferenz (I), Edailson Luís Xavier Guatemim (II), Karine Angélica Dalla Costa (I), Marina Leda Ribeiros (I), Alessandra Farias Millezi (I), Gabriel Bonetto Bampi (II), Sheila Mello da Silveira

(I) IFC - Instituto Federal Catarinense - Campus Concórdia (Rodovia SC 283 - Km 08 - Vila Fragosos - Concórdia - Santa Catarina), (II) UnC - Universidade do Contestado - Campus Concórdia (Rua Victor Sopelsa, 3000, Bairro Salete Concórdia - SC)

\section{Resumo}

Comercializado em diversos países com diferentes denominações, a ricota é um produto cuja principal matéria prima é o soro de leite. Sua fabricação acontece por meio da precipitação das proteínas do soro, através de tratamento térmico e acidificação. Devido à alta umidade, disponibilidade de nutrientes e $\mathrm{pH}$ próximo à neutralidade, proporciona condições adequadas de crescimento para uma ampla variedade de microrganismos que podem afetar a vida de prateleira do produto, comprometendo sua qualidade, além de oferecer riscos à saúde do consumidor. Embora não existam no Brasil padrões de identidade e qualidade específicos para ricotas, este produto enquadra-se como queijo de alta umidade (maior que $55 \%$ ), de acordo com a Resolução RDC n ${ }^{\circ} 12$ da Agência Nacional de Vigilância Sanitária (2001). O presente trabalho foi realizado com o objetivo de avaliar a qualidade microbiológica de ricotas comercializadas na cidade de Concórdia, SC. Foram adquiridas 10 amostras de 5 marcas e de diferentes lotes. As análises foram realizadas no Laboratório de Microbiologia de Alimentos do Instituto Federal Catarinense- Campus Concórdia. As amostras foram identificadas, retiradas da embalagem após desinfecção com álcool 70\%, sob condições assépticas e homogeneizadas para realização das análises microbiológicas. Foram realizadas pesquisa de

\footnotetext{
Referência:

Mariane Ferenz, Edailson Luís Xavier Guatemim, Karine Angélica Dalla Costa, Marina Leda Ribeiros, Alessandra Farias Millezi, Gabriel Bonetto Bampi, Sheila Mello da Silveira. Qualidade Microbiológica de Ricotas Comercializadas Na Cidade de Concórdia, Sc. In: Anais do 12 Congresso Latinoamericano de Microbiologia e Higiene de Alimentos - MICROAL 2014 [= Blucher Food Science Proceedings, num.1, vol.1]. São Paulo: Editora Blucher, 2014.

DOI 10.5151/foodsci-microal-127
} 
Salmonella sp., contagem de estafilococos coagulase positiva, enumeração de coliformes totais e coliformes termotolerantes. A contagem de estafilococos coagulase positiva foi inferior ao limite de 5,0 x $10^{2} \mathrm{UFC} / \mathrm{g}$ em todas as amostras. Além disso, também não foi detectada a presença de Salmonella sp. nas amostras, estando estas em conformidade com a RDC $\mathrm{n}^{\circ} 12$. Das 10 amostras analisadas, 7 apresentaram contaminação por coliformes totais. A legislação brasileira não estabelece limite para este grupo de microrganismos, mas sua presença pode ser indicativa das condições higiênicas em que o produto foi fabricado. Para coliformes termotolerantes, $50 \%$ das amostras apresentaram contaminação, sendo que $30 \%$ ultrapassaram o padrão microbiológico estabelecido pela $\operatorname{RDC} \mathrm{n}^{\circ} 12$, que é $5 \times 10^{2} \mathrm{NMP} / \mathrm{g}$ para amostra indicativa. De modo geral, a qualidade das ricotas comercializadas pode ser considerada satisfatória, porém, atenção especial deve ser dada às boas práticas de fabricação, com treinamento constante de funcionários, uma vez que podem ocorrer falhas que comprometam a qualidade dos produtos.

Palavras-Chave: Coliformes, Estafilococos, Ricotas, Salmonella Agência de Fomento: 